\title{
The relationship between fiscal policy and economic growth in CEE countries*
}

\author{
Sabina Hodžićn , Amer Demirovićn ${ }^{2}$ Emira Bečić ${ }^{3}$
}

\begin{abstract}
The relationship and effects between fiscal policy and economic growth have been an important theoretical and empirical research topic. The neoclassical models imply that the economic effects of changes in government spending will be neutralised by the impact of consequent changes in private spending. Endogenous growth models, on the other hand, imply that changes in the level and composition of taxation and government expenditure can affect economic growth. This aim of the paper is to explore the relationship and effects of fiscal policy and economic growth in 21 Central and Eastern European (CEE) countries over the period 2000-2018. The results, after controlling for various common and country-specific variables, imply that an increase in taxation, but not in non-productive expenditures, can positively affect economic growth. Our main findings are: (i) there is a significant and positive contemporaneous relationship between the general level of taxation and economic growth; and (ii) there is no relationship between the government final consumption and economic growth. Therefore, our results contributed to the scientific literature by providing empirical evidence on the contemporaneous relationship between the general government tax receipt and economic growth in CEE countries.
\end{abstract}

Key words: fiscal policy, economic growth, panel data analysis, Central and Eastern European countries

JEL classification: $\mathrm{H} 20, \mathrm{H} 50, \mathrm{O} 7 \mathrm{7}$

* Received: 02-11-2020; accepted: 21-12-2020

1 PhD, Associate Professor, University of Rijeka, Faculty of Tourism and Hospitality Management, Primorska 42, 51410, Opatija, Croatia. Scientific affiliation: finance, public finance, local government. Phone: +385 51294687.E-mail: sabinah@fthm.hr.ORCID: 0000-0002-4202-3548.

2 PhD, Assistant Professor, Universiti Teknologi Brunei, School of Applied Sciences and Mathematics, Jalan Tungku Link, Gadong BE1410, Brunei Darussalam. Scientific affiliation: econometrics, statistics, economic modelling.Phone: +673 8302451.E-mail: amer.demirovic@ utb.edu.bn.

${ }^{3}$ PhD, Research Associate, Statistical consultant at GOPA Consultants, 10090, Zagreb, Croatia. Scientific affiliation: statistics, public finance, education. Phone: +385 917692730. E-mail: becic.emira@gmail.com. 


\section{Introduction}

In line with economic theory, fiscal policy as a part of overall macroeconomic policy manages budget revenues and expenditures. By using different fiscal instruments, fiscal policy contributes to the achievements of macroeconomic objectives such as full employment, price stability, economic growth, distribution of income, improvements in the balance of payments and others. Moreover, fiscal policy measures like automatic stabilizers and discretionary measures need to be directed to achieve stimulation of economic growth, regulate unemployment and price level, and also redistribution of income and poverty. As such, fiscal policy is the use of government spending and taxation to influence the economy. In that sense, the relationship and effects between fiscal policy and economic growth have been an important theoretical and empirical research topic. Can a change in the share of government expenditure in output, or the structure of expenditure and revenue, improve economic growth, stimulate employment and affect other macroeconomic variables? Therefore, in the economic theory there are three main analytical frameworks through which the determinants of growth including fiscal policy have been analysed - neoclassical growth models, endogenous growth theory and literature that emphasizes the institutional conditions.

The neoclassical growth models (e.g. Solow, 1956) imply that the economic effects of changes in government spending will be neutralised by the effects of consequent changes in private spending. Endogenous growth models (e.g. Barro, 1990), on the other hand, imply that changes in the level and composition of taxation and government expenditure can affect economic growth. Moreover, the preconditions of this model are derived by classifying elements of the government budget into one of four categories. These are distortionary or non-distortionary taxation and productive and non-productive expenditures. Following Kneller et al. (1999) distortionary taxes have effect on agent's investment decision which affect the rate of economic growth, while non-distortionary taxes should not have any effect on investment or saving rates. If government expenditures are classified as productive in that case they have effect on growth, otherwise not. Kneller et al. (1999) find a negative relationship between distortionary taxation (e.g. income tax) and economic growth. On the other hand, they report that an increase in productive government expenditure is positively associated with economic growth. In line with other studies (Bleaney et al. 2001; Gemmell et al. 2011; Zagler and Dürnecker, 2003; Dalić, 2013; Zimčík, 2016) and for the purpose of this empirical analysis we distinguish between distortionary and non-distortionary taxes, and productive and unproductive expenditures. Therefore, taxes on income, profit and social contributions are classified as distortionary, while taxes on goods and services as non-distortionary. In productive expenditures we classified health expenditure, education expenditure, expenditure on economic affairs, expenditure on public order and safety; defence expenditure and expenditure on environment protection, while in non-productive expenditures, social security and 
welfare expenditure; expenditure on general public services; expenditure on housing; and expenditure on recreation. Regarding the institutional conditions, researchers like North and Thomas (1973), Olson (1982), and Djankov et al. (2003) provide the empirical evidence that the fundamental differences in economic growth are caused by the differences in institutions.

Following economic theory and studies, our main hypothesis is that the contemporaneous relationship between the general government tax receipts and economic growth is positive. An examination of a panel dataset covering $21 \mathrm{CEE}$ countries from 2000 to 2018 uncovers a significant positive contemporaneous relationship between the general government tax receipts and economic growth. While the contemporaneous relationship is positive, the relationship between the lagged tax receipts and economic growth is negative. Further, we find no relationship between final government consumption and economic growth. This paper contributes to the literature by examining the relationship between fiscal policy and economic growth in CEE countries from 2000 to 2018.

The paper is organised as follows. In section two, we summarise relevant findings on the relationship between fiscal policy and economic growth reported by other studies. The research methodology is presented in section three, while section four presents the data, data sources and the empirical analysis. Section five presents the results and discusses the findings. The last section provides a conclusion and recommendations for further research.

\section{Literature review}

Kneller et al. (1999) examine the relationship between fiscal policy and economic growth in 22 OECD countries over a period of 25 years. They find that distortionary taxation, unlike non-distortionary taxation, reduces economic growth. Moreover, increasing productive expenditure or reducing distortionary taxes by 1 percent of GDP can increase the growth rate between 0.1 and 0.2 percent per year. Similarly, to taxation, the effect of government expenditures on growth depends on the composition expenditures. An increase in productive expenditure stimulates growth. More recent studies have provided additional insights into the relationship between fiscal policy and economic growth. Saqib et al. (2014) report negative effects on economic activity in Pakistan and suggested that the taxation system should be improved by increasing government expenditures on public services. Edame and Adejumo (2013) show a positive effect of tax revenues on economic growth, while Rosoiu (2015) uncovers a positive relationship between the level of taxation and economic growth. Gupta et al. (2005) analysed whether the fiscal expansions and fiscal consolidation have positive effect for growth in 39 low-income countries with IMF-supported programs in the 1990s. They found that fiscal consolidation have 
positive effect on growth. This occurs in a reduction in the domestic borrowing requirement of the government.

Ram (1986) found a strong and significant positive effect on government spending growth on output growth. On the other hand, Landau $(1983,1986)$, Kormendi and Meguire (1985) and Grier and Tullock (1989) report a negative correlation between government fiscal activity and output growth rates. Finally, researchers Conte and Darrat (1988) and Lindauer and Velenchik (1992) found that there is no significant relation between government consumption and economic growth. By using two multiple linear regressions, Boldeanu et al. (2015) analysed the impact of total expenditure, total revenue, deficit and mainly the effect of fiscal policy on economic growth in ten countries in Eastern Europe.

Easterly and Rebelo (1993) report a strong association between the development level and fiscal structure. According to his analysis, poor countries rely heavily on international trade taxes, while income taxes are only important in developed economies. Therefore, fiscal policy is influenced by the scale of the economy, measured by its population and investment in transport and communication is consistently correlated with growth while the effects of taxation are difficult to isolate empirically.

Kukk (2007) reports that an increase in direct taxes, indirect taxes or grants by one percentage point of the gross domestic product increases growth by around 0.1$0.15,0.1-0.2$ and $0.5-1$ percentage points respectively. He also finds that changes in different revenue and expenditure categories might have the same impact on budget balance and on total government revenue and expenditure, but they have different effects on economic growth in the long run. Maşca et al. (2015) find that a reduction in government expenditures stimulates growth in the European Union.

Taxation influences economic growth mainly through its impact on variables such as capital accumulation and investment, or human capital (Kotlán et al., 2011; Macek, 2014). Zimčík (2016) finds that non-distortionary (production) taxes and unproductive expenditures have a negative impact on economic growth. On a sample of 20 selected European Union Member states over the years 1995 to 2012, Zimčík (2016) finds that most distortionary taxes (except corporate taxes) have negative relationship to economic growth. Obreja Brasoveanu and Brasoveanu (2008) find a link of negative causality between economic growth and fiscal revenues in Romania. Barro (1990) suggests that shifting from distortionary taxes to non-distortionary taxation stimulates growth. He argues that the level of budget expenditures, which can be divided into productive and unproductive expenditures, influences economic growth. Gemmell and Au (2013) found that an increase in productive expenditures financed by a rise in non-distortionary taxation led to enhanced growth. In line with this, Conte and Darrat (1988) find no correlation between government expenditures and economic growth in the OECD countries, 
while Lindauer and Velenchik (1992) obtain the same result from their sample of developing countries. Dalić (2013) analysed the relationship between fiscal policy and growth in new member states and Croatia over the period 1999-2000. The empirical results showed that fiscal policy have positive effects on economic growth. This especially refers to changes in the structure of total expenditure, i.e. reductions in unproductive or current expenditure. Deskar-Škrbić (2018) found that fiscal policy has a significant impact on economic developments in Croatia. None of the existing studies focuses on the impact of the level of taxation on economic growth in CEE countries. In line with the existing literature, we hypothesise that relationship between the level of taxation and economic growth is positive.

\section{Methodology}

Since the data set is two-dimensional, the panel regression models with different fixed effects are used as an analytic tool. The simplest model for the analysis of this two-dimensional data set is given by:

$$
\mathrm{GDPG}_{\mathrm{it}}=\alpha+\beta \mathrm{x}_{\mathrm{it}}+\varepsilon_{\mathrm{it}}, \varepsilon_{\mathrm{it}} \sim \text { i.i.d. }\left(0, \sigma^{2}\right)
$$

where $\mathrm{GDPG}_{\mathrm{it}}$ is the real GDP growth rate of country $i$ in year $t$, a is the intercept, $\mathrm{b}$ is a $\mathrm{k} \mathrm{x} 1$ parameter vector, $\mathrm{x}_{\mathrm{it}}$ is a vector of $\mathrm{k}$ explanatory variables and $\varepsilon_{\mathrm{it}}$ is a disturbance term.

This model is referred to as the constant-coefficient model because it imposes the same coefficient for every country in the sample. This is the most parsimonious panel data model but is severely restricted. Most importantly, by imposing the same intercept for every country, it effectively assumes that other country-specific determinants of the GDP growth rate are the same for all countries. Other countryspecific effects can be taken into account by allowing the intercept to vary in the cross-section. Consider the following model:

$$
\mathrm{GDPG}_{\mathrm{it}}=\alpha_{\mathrm{i}}+\beta \mathrm{x}_{\mathrm{it}}+\varepsilon_{\mathrm{it}}, \varepsilon_{\mathrm{it}} \backsim \text { i.i.d. }\left(0, \sigma^{2}\right)
$$

The subscript $i$ for a indicates that each country has its own intercept or fixed effect. This feature of the model controls for time-invariant country characteristics and therefore provides the basis for the analysis of the effect of the controlled variables that vary over time.

The GDP growth rate is influenced by common factors or factors which affect every country. As with cross-sectional fixed effects, the constant coefficient panel data model can be extended to control for common factors time effects. This is particularly important since the data sample covers the recent global financial crisis. Consider the following model: 


$$
\mathrm{GDPG}_{\mathrm{it}}=\phi_{\mathrm{t}}+\beta \mathrm{x}_{\mathrm{it}}+\varepsilon_{\mathrm{it}}, \varepsilon_{\mathrm{it}} \sim \text { i.i.d. }\left(0, \sigma^{2}\right)
$$

where $\phi_{t}$ is the time-specific effect. This effect is common in the cross-section, so it captures all time-varying variables that affect the GDP growth rate but are constant in the cross-section.

Finally, the following model controls for both effects (country-specific and periodspecific) simultaneously:

$$
\mathrm{GDPG}_{\mathrm{it}}=\alpha_{\mathrm{i}}+\phi_{\mathrm{t}}+\beta \mathrm{x}_{\mathrm{it}}+\varepsilon_{\mathrm{it}}, \varepsilon_{\mathrm{it}} \sim \text { i.i.d. }\left(0, \sigma^{2}\right)
$$

Following Petersen (2009), appropriate clustered standard errors are used to account for potential time-series as well as cross-sectional error correction.

\section{Empirical data and analysis}

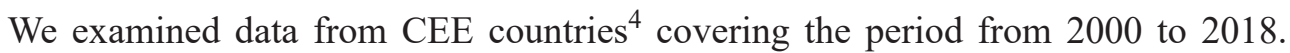
The annual aggregated data is collected from 2000-2018 for 21 CEE countries. The data was obtained from the Handbook of Statistics 2019 of the Vienna Institute for International Economic Studies. The panel dataset is unbalanced as some countryyear observations are not available for the entire sample period. The total number of country-year observations available is 321 . The GDP growth rate is sutilised as dependent variable, while the explanatory variables are the growth rate of total tax receipts-general government, growth rate of government final consumption expenditure and growth rate of total population. Growth rates of gross fixed capital formation, total employment and consumer prices are used as control variables. Table 1 depicts the descriptive statistics of the panel series.

\footnotetext{
4 Albania, Bosnia and Herzegovina, Bulgaria, Croatia, Czech Republic, Estonia, Hungary, Kazakhstan, Kosovo, Latvia, Lithuania, Macedonia, Montenegro, Poland, Romania, Russia, Serbia, Slovakia, Slovenia, Turkey, Ukraine
} 
Sabina Hodžić, Amer Demirović, Emira Bečić • The relationship between fiscal policy...

Table 1: Descriptive statistics of panel series

\begin{tabular}{|l|c|c|c|c|}
\hline Growth Rates in \% & Mean & Std. Dev. & Min & Max \\
\hline GDP & 3.6 & 3.9 & -15.1 (Ukraine) & 13.5 (Kazakhstan) \\
\hline Gov. Tax Receipts & 3.9 & 8.0 & -36.2 (Latvia) & 84.0 (Serbia) \\
\hline Gov. Final Consumption & 2.0 & 4.3 & -15.8 (Macedonia) & 35.5 (Macedonia) \\
\hline Employment & 0.6 & 3.1 & -14.3 (Macedonia) & 21.9 (Montenegro) \\
\hline Population & -0.7 & 4.9 & -16.2 (Lithuania) & 16.4 (Kazakhstan) \\
\hline Capital Formation & 5.2 & 12.3 & -49.7 (Ukraine) & 50.5 (Romania) \\
\hline Consumer Prices & 5.8 & 9.2 & -2.4 (Kosovo) & 93.3 (Serbia) \\
\hline
\end{tabular}

Source: Authors' calculation

The GDP growth rate is regressed on the real growth rate in gross total general government tax receipts, government final consumption expenditure, total employment, population, fixed capital formation and consumer prices. The estimated coefficients and associated t-statistics of the panel models specified in Equations 1-4 are presented in Table 2.

Table 2: The relationship between the GDP growth rate and the variables

\begin{tabular}{|c|c|c|c|c|c|c|c|c|}
\hline \multirow{2}{*}{$\begin{array}{c}\text { Variable } \\
\text { (growth rates in \%) }\end{array}$} & \multicolumn{2}{|c|}{$\begin{array}{l}\text { No Effects } \\
\text { (Eq. 1) }\end{array}$} & \multicolumn{2}{|c|}{$\begin{array}{c}\text { Country Effects } \\
\text { (Eq. 2) }\end{array}$} & \multicolumn{2}{|c|}{$\begin{array}{l}\text { Period Effects } \\
\text { (Eq. 3) }\end{array}$} & \multicolumn{2}{|c|}{$\begin{array}{c}\text { Two-Way } \\
\text { Effects (Eq. 4) }\end{array}$} \\
\hline & Coeff. & T-stat & Coeff. & T-stat & Coeff. & T-stat & Coeff. & T-stat \\
\hline Gov. Tax Receipts & 0.16 & $8.87 *$ & 0.16 & $4.89 *$ & 0.11 & $6.87 *$ & 0.12 & $6.85^{*}$ \\
\hline $\begin{array}{l}\text { Gov. Tax Receipts } \\
(-1)\end{array}$ & -0.06 & $-3.03 *$ & -0.04 & -1.58 & -0.04 & $-2.09^{*}$ & -0.03 & $-2.04 *$ \\
\hline $\begin{array}{l}\text { Gov. Final } \\
\text { Consumption }\end{array}$ & 0.09 & $2.44 *$ & 0.06 & 1.23 & 0.07 & $2.03^{*}$ & 0.05 & 1.35 \\
\hline Employment & 0.16 & $3.20 *$ & 0.19 & $3.12 *$ & 0.16 & $4.64 *$ & 0.19 & $4.39 *$ \\
\hline Population & -0.03 & -1.06 & -0.12 & $-2.82 *$ & 0.00 & -0.10 & -0.06 & -1.35 \\
\hline Capital Formation & 0.18 & $15.05^{*}$ & 0.18 & $6.05^{*}$ & 0.13 & $7.01 *$ & 0.12 & $10.10^{*}$ \\
\hline Consumer Prices & -0.05 & $-3.41 *$ & -0.06 & $-2.82 *$ & -0.06 & $-3.16^{*}$ & -0.08 & $-4.42 *$ \\
\hline GDPG(-1) & 0.16 & $4.18 *$ & 0.11 & 1.56 & 0.26 & $5.24 *$ & 0.18 & $3.98 *$ \\
\hline $\mathrm{C}$ & 1.43 & $8.43 *$ & 1.54 & $4.20^{*}$ & 1.54 & $8.70^{*}$ & 1.87 & $9.24 *$ \\
\hline Adjusted $\mathrm{R}^{2}$ & \multicolumn{2}{|c|}{$\frac{1}{75 \%}$} & \multicolumn{2}{|c|}{$76 \%$} & \multicolumn{2}{|c|}{$83 \%$} & \multicolumn{2}{|c|}{$84 \%$} \\
\hline
\end{tabular}

Note: *significance at the $5 \%$ level; ** significance at the $10 \%$ level

Source: Authors' calculation 
The explanatory power, as measured by the Adjusted $\mathrm{R}^{2}$, indicated that the twoway effects model (Equation 4) is the best. The country-specific effects improve the explanatory power by just one percentage point, and the year-specific effects improve the explanatory power by eight percentage points. This implies that common factors that affect the GDP growth rate of all the countries are more important that country-specific factors or differences among individual countries.

The formal tests, depicted in Table 3 (below), confirm that the cross-sectional factors are less important to the period-effects. However, both the F-test and Chisquare tests indicate that they are not redundant. Similarly, both tests strongly confirm the importance of the period effects. Therefore, the two-way effects model or the period effects model should be used. It should be noted that the coefficients in models without the period effects are biased. Using the robust errors to account for the cross-sectional correlation of errors, as in Zimčík (2016), corrects the bias in standard errors of the coefficients, but leaves the coefficients inflated.

Table 3: Fixed Effects Redundancy Tests

\begin{tabular}{|l|r|r|c|}
\hline \multicolumn{1}{|c|}{ Effects Test } & \multicolumn{1}{c|}{ Statistic } & \multicolumn{1}{c|}{ d.f. } & Prob. \\
\hline Cross-section F & 1.96 & $-20,257.00$ & 0.01 \\
\hline Cross-section Chi-square & 43.11 & 20.00 & 0.00 \\
\hline Period F & 8.24 & $-17,257.00$ & 0.00 \\
\hline Period Chi-square & 131.82 & 17.00 & 0.00 \\
\hline Cross-Section/Period F & 5.27 & $-37,257.00$ & 0.00 \\
\hline Cross-Section/Period Chi-square & 170.99 & 37.00 & 0.00 \\
\hline
\end{tabular}

Source: Authors' calculation

The results indicate that the general government tax receipts are positively and significantly related to the GDP growth rate. The magnitude of the coefficient implies that 1 percent growth in the general government tax receipts increases GDP by 0.12 percent. On the other hand, the relationship between the lagged general government tax receipts and the GDP growth rate is negative. This implies that an increase in the general government tax receipts stimulates the growth in the period when it occurs, but negatively impacts upon growth in the subsequent period. On the other hand, there is no relationship between final government consumption and GDP growth rates. This implies that growth in taxation to finance productive expenditures boosts economic growth. 


\section{Results and discussion}

Fiscal policy, as a part of overall macroeconomic policy, manages budget revenues and expenditures. By using different fiscal instruments, fiscal policy contributes to the achievements of macroeconomic objectives such as full employment, price stability, economic growth, distribution of income, improvements in the balance of payments etc. The relationship between fiscal policy and economic growth has been studied by many authors with no conclusive results. One branch of the literature (e.g. Ram, 1986; Gemmel et al., 2011; Sever et al., 2011; Edame and Adejumo, 2013; Šimović and Deskar-Škrbić, 2013; Maşca et al., 2015; Rosoiu, 2015; DeskarŠkrbić, 2018) finds a positive and significant relationship between fiscal policy and economic growth, while other researchers (Landau 1983, 1986; Grier and Tullock, 1989; Barro, 1990; Gwartney et al. 1998; Bajo-Rubbio, 2000; Obreja Brasoveanu and Brasoveanu, 2008; Saqib et al., 2014; Zimčík, 2016) reports significantly negative or no significant relationship between fiscal policy and economic growth (Conte and Darrat, 1988; Lindauer and Velenchik, 1992). Due to the economic and financial circumstances in CEE countries, fiscal policy is an important instrument for stabilising domestic demand and output and promoting sustainable and robust growth. As one of the most important economic instrument, fiscal policy produces numerous direct as well as indirect effects on the stability of prices, employment, economic growth, the balance of payment, redistribution of income and property, aggregate demand, liquidity etc. From the traditional fiscal literature, it follows that expansionary fiscal policy can affect aggregate expenditure and, consequently, economic growth.

By observing empirical results, the results imply a positive contemporaneous relationship between the general government tax receipts and economic growth of 21 CEE countries within the period 2000 - 2018. Moreover, one percentage point increase in general government tax receipts boosts economic growth by 0.12 percentage points. Thus, the results, in general, are in line with our main hypothesis. Further, our results are in line with Deskar-Škrbić (2018) who studied one CEE country (i.e. Croatia). On the other hand, the relationship between the lagged general government tax receipts and economic growth is found to be negative. This implies the initial positive impact of an increase in tax receipts on economic growth is at least partially neutralised in subsequent periods. The results are robust to explicit controls for changes in employment, population, capital formation, consumer prices and lagged GDP growth rate as well as general fixed crosssectional and period effects. We also find no significant relationship between final government consumption and economic growth, which is consistent with the results reported by Conte and Darrat (1988) and Lindauer and Velenchik (1992). On the other hand, Dalić (2013) found that the high volatility of government investment has its own negative direct on growth. In order to achieve positive effect of fiscal policy on growth it is necessary to improve fiscal balance. This can be achieved 
by either cutting unproductive expenditure or a combination of a reduction in unproductive expenditure and an increase in non-distortionary taxes. Our results contribute to the literature in several ways. Firstly, we examine CEE countries, which are not extensively covered by the existing literature. Secondly, our results provide additional evidence on the contemporaneous relationship between the general government tax receipts and economic growth.

\section{Conclusions}

We hypothesise that the contemporaneous relationship between the level of taxation and economic growth is positive. An analysis of a sample of $21 \mathrm{CEE}$ countries spanning 18 years leads to the acceptance of this hypothesis. An increase in taxation is associated with higher economic growth in the same period and negative economic growth in the subsequent period. This implies that the fiscal policy can be used to boost economic growth in the short term. In addition, the fiscal policy is especially perceived in connection with basic functions, such as allocation, stabilization and redistribution. The finding that there is no relationship between final government consumption and economic growth points out that the best effect is achieved when additional tax revenues are used to fund capital expenditures. All presented results have important policy implications since fiscal policy as one of the most important economic instrument produces numerous effects direct or indirect. Moreover, expansionary fiscal policy has effects on expenditure and aggregate demand and, also with that on direct or indirect way on economic growth. We contribute to the literature by examining a sample of CEE countries not extensively studied before. The research is limited by the availability of data and can be extended by examining the relationship between economic growth and various components of government revenues and expenditures.

\section{Acknowledgments}

This paper has been financially supported by the University of Rijeka within the framework of the "Pametni gradovi u funkciji razvoja nacionalnog gospodarstva" (uniri-drustv-18-255-1424) project.

\section{References}

Bajo-Rubbio, O. (2000) "A further generalisation of the Solow growth model: the role of the public sector”, Economic Letters, Vol. 68, No. 1, pp. 79-84.

Barro, R. J. (1990) "Government Spending in a Simple Model of Endogenous Growth", Journal of Political Economy, Vol. 98, No. 5, pp. 103-117, https:// doi.org/10.1086/261726. 
Bleaney, M., Gemmell, N. Kneller, R. (2001) "Testing the Endogenous Growth Model; Public Expenditure, Taxation and Growth over the Long Run", Canadian Journal of Economics, Vol. 34, No. 1, pp. 36-57, https://doi. org/10.1111/0008-4085.00061.

Boldeanu, F. T., Tache, I., Ion Madălin, S. (2015) "The impact of fiscal policy on economic growth in the countries of Eastern Europe", Revista Economica, Vol. 67, No. 5, pp. 16-32.

Conte, M. A., Darrat, A. F. (1988) "Economic Growth and the Expanding Public Sector: A Reexamination", The Review of Economics and Statistics, Vol. 70, No. 2, pp. 322-330.

Dalić, M. (2013) "Fiscal policy and growth in the new member states of the EU: a panel data analysis", Financial Theory and Practice, Vol. 37, No. 4, pp. 335360, https://doi.org/10.3326/fintp.37.4.1.

Deskar-Škrbić, M. (2018) "Dynamic effects of fiscal policy in Croatia: confronting New-Keynesian SOE theory with empirics", Proceedings of Rijeka Faculty of Economics: Journal of Economics and Business, Vol. 36, No. 1, pp. 83-102.

Djankov, S. et al. (2003) "The New Comparative Economics", Journal of Comparative Economics, Vol. 31, No. 4, pp. 595-619, https://doi.org/10.1016/j. jce.2003.08.005.

Easterly, W., Rebelo, S. (1993) "Fiscal policy and economic growth: an empirical investigation", Journal of Monetary Economics, Vol. 32, No. 3, pp. 417-458, https://doi.org/10.1016/0304-3932(93)90025-B.

Edame, G. E., Adejumo, T. O. (2013) "The effects of Tax Revenue on Economic Growth in Nigeria (1970-2011)", International Journal of Humanities and Social Science Invention, Vol. 2, No. 6, pp. 16-26.

Gemmell, N., Au, J. (2013) "Government size, fiscal policy and the level and growth output: A review of recent evidence", Journal of the Asia Pacific Economy, Vol. 18, No. 2, pp. 203-229, https://doi.org/10.1080/13547860.2013. 777535.

Gemmell, N., Kneller, R., Sanz, I. (2011) "The Timing and Persistence of Fiscal Policy impacts on Growth: Evidence from OECD Countries", Economic Journal, Vol. 121, No. 55, pp. F33-F58, https://doi.org/10.1111/j.1468-0297. 2010.02414.x.

Grier, K. B., Tullock, G. (1989) "An Empirical Analysis of Cross-National Economic Growth", Journal of Monetary Economics, Vol. 24, No. 2, pp. 259276, https://doi.org/10.1016/0304-3932(89)90006-8.

Gupta, S., Clements, B., Baldacci, E., Mulas-Granados, C. (2005) "Fiscal policy, expenditure composition, and growth in low-income countries", Journal of International Money and Finance, Vol. 24, pp. 441-463, doi: 10.1016/j. jimonfin.2005.01.004. 
Gwartney, J., Lawson, R., Holcombe, R. (1998) The size and functions of government and economic growth, Joint Economic Committee Study, Washington D.C.

Kneller, R., Bleaney, M. F., Gemmell, N. (1999) "Fiscal policy and growth: evidence from OECD countries", Journal of Public Economics, Vol. 74, No. 2, pp. 171-190, https://doi.org/10.1016/S0047-2727(99)00022-5.

Kormendi, R. C., Meguire, P. G. (1985) "Macroeconomic Determinants of Growth: Cross-Country Evidence", Journal of Monetary Economics, Vol. 6, No. 2, pp. 141-163, https://doi.org/10.1016/0304-3932(85)90027-3.

Kotlán, I., Machová, Z., Janíčkova, L. (2011) "Taxation Influence on Economic Growth”, Politická ekonomie. Vol. 59, No. 5, pp. 638-658, https:// doi.org/ 10.18267/j.polek.812.

Kukk, K. (2007) Fiscal Policy Effects on Economic Growth: Short Run vs. Long Run, TTU Working Paper No. 167, pp. 77-96.

Landau, D. (1983) "Government Expenditure and Economic Growth: A CrossCountry Study", Southern Economic Journal, Vol. 49, pp. 783-792, https://doi. org/10.2307/1058716.

Landau, D. (1986) "Government and Economic Growth in the Less Developed Countries: An Empirical Study for 1960-1980", Economic Development and Cultural Change, Vol. 35, No. 1, pp. 35-75, https://doi.org/10.1086/451572.

Lindauer, D. L., Velenchik, A. D. (1992) "Government spending in developing countries: trends, causes, and consequences", The World Bank Research Observer, Vol. 7, No. 1, pp. 59-78, https://doi.org/10.1093/wbro/7.1.59.

Macek, R. (2014) "The Impact of Taxation on Economic Growth: Case Study of OECD Countries", Review of Economic Perspectives, Vol. 14, No. 4, pp. 309328, https://doi.org/10.1515/revecp-2015-0002.

Maşca, S. G., Cuceu, I. C., Văidean, V. L. (2015) "The Fiscal Policy as Growth Engine in EU countries", Procedia Economics and Finance, Vol. 32, pp. 16281637, https://doi.org/10.1016/S2212-5671(15)01489-6.

North, D., Thomas, R. (1973) The Rise of the Western World: A New Economic History, Cambridge: Cambridge University Press.

Obreja Brasoveanu, L., Brasoveanu, I. (2008) "The Correlation between Fiscal Policy and Economic Growth", Theoretical and Applied Economics, Vol. 7, No. 524, pp. 19-26.

Olson, M. (1982) The Rise and Decline of Nations, Yale: Yale University Press.

Petersen, M. A. (2009) "Estimating Standard Errors in Finance Panel Data Sets: Comparing Approaches", The Review of Financial Studies, Vol. 22, No. 1, pp. 435-480, Available at: <http://www.jstor.org/stable/40056916>.

Ram, R. (1986) "Government Size and Economic Growth: A New Framework and Some Evidence from Cross-Section and Time-Series Data", American Economic Review, Vol. 76, No. 1, pp. 191-203, Available at: < https://www.jstor.org/ stable/1804136>. 
Rosoiu, I. (2015) "Uncertainty and the Transmission of Fiscal Policy", Procedia Economics and Finance, Vol. 32, pp. 769-776, https://doi.org/10.1016/S22125671(15)01460-4.

Saqib, S. et al. (2014) "Taxation Effects on Economic Activity in Pakistan", Journal of Finance and Economics, Vol. 2, No. 6, pp. 215-219, https://doi.org/10.12691/ jfe-2-6-3.

Sever, I., Drezgić, S., Blažić, H. (2011) "Budget spending and economic growth in Croatia - Dynamics and relationship over the past two decades", Proceedings of Rijeka Faculty of Economics: Journal of Economics and Business, Vol. 29, No. 2, pp. 291-331.

Solow, R.M. (1956) "A contribution to the theory of economic growth", Quarterly Journal of Economics, Vol. 71, No. 1, pp. 65-94, https://doi.org/10.2307/ 1884513.

Šimović, H., Deskar-Škrbić, M. (2013) "Dynamic effects of fiscal policy and fiscal multipliers in Croatia", Proceedings of Rijeka Faculty of Economics: Journal of Economics and Business, Vol. 31, No. 1, pp. 55-78.

Vienna Institute for International Economic Studies (2019), Handbook of Statistics 2019: Central, East and Southeast Europe, Available at: https://wiiw.ac.at/ wiiw-handbook-of-statistics-2019-central-east-and-southeast-europe-p-5109. html.

Zagler, M., Dürnecker, G. (2003) "Fiscal Policy and Economic Growth", Journal of Economic Surveys, Vol. 17, No. 3, pp. 397-418, https://doi.org/10.1111/14676419.00199.

Zimčík, P. (2016) "Economic Growth and Budget Constraints: EU Countries Panel Data Analysis", Review of Economic Perspectives, Vol. 16, No. 2, pp. 87-101, https://doi.org/ 10.1515/revecp-2016-0007. 


\title{
Povezanost fiskalne politike i gospodarskog rasta u zemljama srednje $\mathrm{i}$ istočne Europe
}

\author{
Sabina Hodžić ${ }^{1}$, Amer Demirović ${ }^{2}$ Emira Bečićc
}

\begin{abstract}
Sažetak
Povezanost $i$ efekti između fiskalne politike $i$ gospodarskog rasta važna su teoretska i empirijska tema istraživanja. Neoklasični modeli smatraju da će ekonomski učinci u državnoj potrošnji biti neutralizirani efektima posljedičnih promjena u privatnoj potrošnji. S druge strane, endogeni modeli rasta smatraju da promjene u razini i sastavu oporezivanja i državne potrošnje utječu na gospodarski rast. Cilj rada je istražiti povezanost i efekte fiskalne politike i gospodarskog rasta u 21 zemlji srednje $i$ istočne Europe u razdoblju od 2000. - 2018. godine. Empirijski rezultati, nakon kontrole zajedničkih i specifičnih varijabli za pojedinu zemlju, ukazuju na to da povećanje oporezivanja, ali ne i neproduktivnih izdataka, može pozitivno utjecati na gospodarski rast. Glavni rezultati empirijske analize su: (i) da postoji značajna i pozitivna povezanost između opće razine oporezivanja $i$ gospodarskog rasta; $i$ (ii) da ne postoji povezanost između državne finalne potrošnje i gospodarskog rasta. Rezultati empirijske analize doprinjeli su znanstvenoj literaturi potvrđujući povezanost između državnih poreznih prihoda $i$ ekonomskog rasta u zemljama srednje i istočne Europe.
\end{abstract}

Ključne riječi: fiskalna politika, ekonomski rast, analiza panel podataka, zemlje srednje $i$ istočne Europe

JEL klasifikacija: H20, H50, O47

${ }^{1}$ Izvanredni profesor. Sveučilište u Rijeci, Fakultet za menadžment u turizmu i ugostiteljstvu, Primorska 42, 51410, Opatija, Hrvatska. Znanstveni interes: financije, javne financije, lokalna uprava.Tel.: +385 51294687.E-mail: sabinah@fthm.hr. ORCID: 0000-0002-4202-3548.

2 Docent. Sveučilište u Bruneju, Fakultet za primijenjenu znanost i matematiku, Jalan Tungku Link, Gadong BE1410, Brunei Darussalam. Znanstveni interes: ekonometrija, statistika, ekonomsko modeliranje.Tel.: +673 8302451.E-mail: amer.demirovic@utb.edu.bn.

3 Znanstvena suradnica. Statistički konzultant za GOPA Consultants, 10090, Zagreb, Hrvatska. Znanstveni interes: statistika, javne financije, obrazovanje. Tel.: +385 917692730. E-mail: becic.emira@gmail.com. 